\title{
KISS1 Gene Product
}

National Cancer Institute

\section{Source}

National Cancer Institute. KISS1 Gene Product. NCI Thesaurus. Code C136718.

A protein encoded by the KISS1 gene. 